\title{
Influence of sucrosis on the degradation of pesticide by white rot fungus
}

\author{
Influência dla sacarose na degradação de pesticida por fungo da podrioidão branca \\ Influencia de la sacarosa en la degradación de plaguicidas por el hongo de la putrefacción blanca
}

Recebido: 04/11/2021 | Revisado: 12/11/2021 | Aceito: 17/11/2021 | Publicado: 27/11/2021

\author{
Victória Maura Silva Bermúdez \\ ORCID: https://orcid.org/0000-0002-8105-8735 \\ Federal University of Ceará, Brazil \\ E-mail: vmsbermudez@gmail.com \\ Letícia Bezerra Farias \\ ORCID: https://orcid.org/0000-0002-2116-9556 \\ Federal Institute of Education, Science and Technology of Ceará, Brazil \\ E-mail: letbezerra31@ @otmail.com \\ Lia Teles Lima \\ ORCID: https://orcid.org/0000-0003-2085-9843 \\ Federal Institute of Education, Science and Technology of Ceará, Brazil \\ E-mail: liateles.92@gmail.com \\ Bárbara Chaves Aguiar Barbosa \\ ORCID: https://orcid.org/0000-0002-1151-9540 \\ Federal Institute of Education, Science and Technology of Maranhão, Brazil \\ E-mail: barbara.barbosa@ifma.edu.br \\ Kelly de Araújo Rodrigues Pessoa \\ ORCID: https://orcid.org/0000-0003-4340-0269 \\ Federal Institute of Education, Science and Technology of Ceará, Brazil \\ E-mail: kellyarpessoa@gmail.com \\ Gloria Maria Marinho Silva \\ ORCID: https://orcid.org/0000-0002-2515-5856 \\ Federal Institute of Education, Science and Technology of Ceará, Brazil \\ E-mail: gloriamarinho@gmail.com
}

\begin{abstract}
The influence of sucrose on the removal of Paraquat (PQT) in synthetic aqueous medium was evaluated by Phanerochaete chrysosporium. Initially, a toxicity test was performed on plates containing paraquat at concentrations of 1, 5, 10, 20 and $30 \mathrm{mg} \cdot \mathrm{L}^{-1}$. Then, they were carried out in batches - agitated batch (RBA) and sequential batch (RBS). Four reactors were submitted, containing medium with $30 \mathrm{mg} . \mathrm{L}^{-1}$ of paraquat, under a reaction time of $144 \mathrm{~h}$, the reactors being RBA-2 and RBS-2 with the addition of $2 \mathrm{gL}^{-1}$ of sucrose, and without the adding sucrose to the RBA-0 and RBS-0 reactors. In all reactors, paraquat was removed, but in RBS-0, the best mean removal efficiency was obtained $(41.1 \pm 0.89 \%)$. The best values of apparent speed of degradation $(\mathrm{k})$ were found in reactors with sucrose RBA-2 and RBS-2, $0.015 \pm 0.002 \mathrm{~h}^{-1}$ and $0.018 \pm 0.002 \mathrm{~h}^{-1}$, respectively, indicating that the addition of sucrose influenced the speed removal of paraquat. It was also verified that the pollutant was not completely removed by adsorption to fungal biomass, which microorganisms predominated in the medium at the end of the treatment, demonstrating their role in the paraquat bioremediation process. Therefore, the addition of sucrose influenced the removal speed of the PQT and COD, but not the removal efficiency.
\end{abstract}

Keywords: Bioremediation; Co-substrate; Fungus; Herbicide.

\section{Resumo}

Foi avaliada a influência da sacarose na remoção do Paraquat (PQT) em meio aquoso sintético por Phanerochaete chrysosporium Inicialmente, foi feito teste de toxicidade em placas contendo paraquat nas concentrações de 1, 5, 10, 20 e $30 \mathrm{mg}$. L $\mathrm{L}^{-1}$. Em seguida, foram realizadas em bateladas - batelada agitada (RBA) e batelada sequencial (RBS). Submeteu-se 4 reatores, contendo meio com $30 \mathrm{mg}^{-1} \mathrm{~L}^{-1}$ de paraquat, sob um tempo de reação de $144 \mathrm{~h}$, sendo os reatores RBA-2 e RBS- 2 com adição de $2 \mathrm{gL}^{-1}$ de sacarose, e sem a adição de sacarose os reatores RBA-0 e RBS-0. Em todos os reatores houve remoção de paraquat, porém em RBS-0, foi obtida a melhor eficiência média de remoção $(41,1 \pm 0,89 \%)$. Os melhores valores da velocidade aparente de degradação $(\mathrm{k})$ foram encontradas nos reatores com sacarose RBA-2 e RBS-2, 0,015 $\pm 0,002 \mathrm{~h}^{-1}$ e $0,018 \pm 0,002 \mathrm{~h}^{-1}$, respectivamente, indicando que a adição de sacarose influenciou a velocidade de remoção do paraquat. Verificou-se também que a remoção do poluente não foi totalmente por adsorção deste à biomassa fúngica, micro-organismos estes que predominaram no meio no final do tratamento, demonstrando a atuação destes no processo de biorremediação do paraquat. Logo, a adição da sacarose influenciou na velocidade de remoção do PQT e DQO, mas não na eficiência de remoção.

Palavras-chave: Biorremediação; Cossubstrato; Fungos; Herbicida. 


\section{Resumen}

La influencia de la sacarosa en la remoción de Paraquat (PQT) en medio acuoso sintético fue evaluada por Phanerochaete chrysosporium. Inicialmente, se realizó una prueba de toxicidad en placas que contenían paraquat en concentraciones de 1, 5, 10, 20 y $30 \mathrm{mg}$. $\mathrm{L}^{-1}$. Luego, se llevaron a cabo en lotes: lote agitado (RBA) y lote secuencial (RBS). Se sometieron cuatro reactores, conteniendo medio con $30 \mathrm{mg}$. $\mathrm{L}^{-1}$ de paraquat, en un tiempo de reacción de 144 h, siendo los reactores RBA-2 y RBS-2 con la adición de 2 g. $\mathrm{L}^{-1}$ de sacarosa, y sin la adición de sacarosa a los reactores RBA-0 y RBS-0. En todos los reactores se eliminó el paraquat, pero en el RBS-0 se obtuvo la mejor eficiencia media de eliminación $(41,1 \pm 0,89 \%)$. Los mejores valores de velocidad aparente de degradación (k) se encontraron en reactores con sacarosa RBA-2 y RBS-2, $0.015 \pm 0.002 \mathrm{~h}^{-1}$ y $0.018 \pm 0.002 \mathrm{~h}^{-1}$, respectivamente, indicando que la adición de sacarosa influyó en la velocidad. eliminación de paraquat. También se verificó que el contaminante no fue removido completamente por adsorción a biomasa fúngica, microorganismos que predominaron en el medio al final del tratamiento, demostrando su rol en el proceso de biorremediación del paraquat. Por lo tanto, la adición de sacarosa influyó en la velocidad de eliminación de PQT y DQO, pero no en la eficiencia de eliminación.

Palabras clave: Biorremediación; Co-sustrato; Herbicida; Hongo.

\section{Introduction}

Environmental pollution from pesticide use is seen as a serious problem due to its adverse effect on human health, plants and animals (Galic et al., 2018; Pandiselvam et al., 2020). Pesticides are chemical compounds that are highly required in agricultural activities, as they are efficient in controlling and eliminating pests, contributing to the maintenance of the quality and yield of agricultural products (Hyland \& Laribi, 2017). However, the careless use of these chemicals can contribute negatively on the environment and, thus, consequently, on human health (Abhilash \& Singh, 2009; Han et al., 2015; Rowland et al., 2011).

The negative effects of pesticide exposure on human health depend mainly on the toxicological profile of the product, as well as on the intensity and exposure, which can occur through inhalation, ingestion and skin contact, resulting in acute and chronic health problems (Pereira, 2011, Lopes \& Albuquerque, 2018). Exposure increases the risk of the emergence of several pathologies, especially cancerous tumors, in addition to hormonal disorders and congenital malformation (Vasconcelos, 2018; Lemarchand et al. 2017; Lerro et al. 2019).

Paraquat is a non-selective contact herbicide used and banned in over 50 countries due to its high chemical toxicity (Wesseling et al., 2001). It is known and marketed as gramoxone, gramocil, agroquat, gramuron and paraquol, or also as a constituent in mixtures with other active ingredients, as in secamate (Serra, Domingos \& Prata, 2003). Its classification regarding the potential environmental hazard is II (Very Dangerous) and its toxicological class is type I (Highly Toxic) (Anvisa, 2005). In regions of agricultural development, with high plantations, paraquat is the main source of pollution of water and soil resources (Sorolla et al., 2012). Exposure to this pollutant can cause serious side effects (Dong et al., 2013; Fukushima et al., 2002; Song et al., 2020) and has been used as a method of suicide (Wu et al., 2014). This active ingredient is banned in Brazil since September 22, 2020, as a result of a toxicological re-evaluation, as provided by Resolution RDC No. 177 of September 21, 2017, published in the Official Gazette of the Union of September 22, 2017.

Because of its polluting potential, it is necessary to seek ways to eliminate it from the environment. In the literature one can find works that perform the degradation of Paraquat from photocatalysts (WONGCHAROEN \& PANOMSUWAN, 2018), by adsorption (Suo et al., 2019), zeolite (Keawkumay et al., 2019) and by bioremediation (Wongputtisin et al., 2021). Bioremediation or biological remediation being a technique in which natural microorganisms such as bacteria, fungi, yeast and enzymes (present or added to the site) are used in the biochemical degradation of organic and inorganic contaminants present in soils, waters and various other environments (Bernoth et al., 2000; Sanchéz et al., 2013).

According to Jou \& Huang (2002) bioremediation is an economical and efficient technique for the elimination of pollutants in aqueous media. Fungi have been showing great versatility in remediating polluted environments, because they are able to grow and survive in high concentrations of contaminating compounds, use them as a source for obtaining energy, in addition to what 
are shown to be skillful organisms in the synthesis of enzymes that act in the safe removal of contaminants from the environment (Das \& Dash, 2014).

On an industrial scale it is of utmost importance the reaction time in which the synthetic water will be treated, i.e. the yield is one of the important factors to determine the operation cost. Therefore, the faster the degradation reaction occurs, the lower the cost. Hence the need for a study on the addition of a carbon source that can accelerate the reaction time.

From the bioremediation with fungi, this research seeks to evaluate the kinetics and the influence of sucrose, as a carbon source, in the efficiency of removal of pesticide Paraquat in stirred batch and sequential reactors, inoculated with Phanerochaete chrysosporium (PHC) using synthetic effluent doped with $30 \mathrm{mg} \cdot \mathrm{L}^{-1}$ of paraquat.

\section{Methodology}

The research is of the quantitative experimental type carried out on a laboratory scale (Pereira et al., 2018), in which mathematical analyzes were carried out based on the results obtained, such as means, standard deviations, percentages and statistics. The work was carried out at the Environmental Technology Laboratory (LATAM) of the Federal Institute of Education, Science and Technology of Ceará (IFCE). The present research was divided into 5 steps: (I) plate toxicity test, (II) cultivation and counting of fungal spores, (III) assembly and operation of the reactors, (IV) adsorption test and (V) contamination evaluation.

\section{(I) Plaque Toxicity Test}

This step consisted in evaluating the tolerance capacity of the fungus Phanerochaete chrysosporium to the pollutant under study. Petri dishes containing Martin culture medium were prepared and different concentrations of Paraquat (1 mg.L $\mathrm{L}^{-1}$, $5 \mathrm{mg} . \mathrm{L}^{-1}, 10 \mathrm{mg} . \mathrm{L}^{-1}, 20 \mathrm{mg} . \mathrm{L}^{-1}$ and $30 \mathrm{mg} \cdot \mathrm{L}^{-1}$ ) were used. The fungus was inoculated using the $6 \mathrm{~mm}$ diameter mycelium plugs methodology (OTTONI, 2012). The growth of the fungal species was observed for 7 days by photographic recording and measurement of colony diameters at the times of $0 \mathrm{~h}, 24 \mathrm{~h}, 72 \mathrm{~h}, 120 \mathrm{~h}$ and $168 \mathrm{~h}$. The measurement was performed with the help of a pachymeter.

\section{(II) Cultivation and counting of fungal spores}

Phanerochaete chrysosporium was grown in Petri dishes with culture medium with the following composition: 2 $\mathrm{mg} . \mathrm{L}^{-1}$ yeast extract, $20 \mathrm{mg} . \mathrm{L}^{-1}$ glucose, $20 \mathrm{mg} . \mathrm{L}^{-1} \mathrm{~K}_{2} \mathrm{HPO}_{4}, 0.6 \mathrm{mg} . \mathrm{L}^{-1} \mathrm{KH}_{2} \mathrm{PO}_{4}, 0.5 \mathrm{mg} . \mathrm{L}^{-1} \mathrm{MgSO}_{4}$, and $2 \mathrm{mg} . \mathrm{L}^{-1}$ peptone. The culture was kept in a microbiological oven under $28^{\circ} \mathrm{C}$ for seven days. Afterwards, the spores were removed with the help of isotonic Tween 80 solution and were stored in a sterile vial for later microscopic counting in a Neubauer chamber. A concentration of $2 \times 10^{6}$ spores $/ \mathrm{mL}$ was used for the reactor inoculum.

\section{(III) Assembly and operation of reactors}

The highest paraquat concentration tested at which fungus growth occurred in the plate test was chosen to be studied in the batch reactors. The synthetic water was prepared using a concentration of $30 \mathrm{mg} \cdot \mathrm{L}^{-1}$ of PQT added to the water supply. - Stirred batch reactors with dispersed biomass

The stirred batches were performed in a bench-top incubator with rotary shakers, at $150 \mathrm{rpm}$ and $30^{\circ} \mathrm{C} \pm 2$. The reactors were erlenmeyer flasks with a reaction volume of $200 \mathrm{~mL}$ (useful volume of $250 \mathrm{~mL}$ ), previously sterilized in autoclaves, and sealed with aluminum foil and Nonwoven Fabric to prevent contamination. The reactors were packed with newspaper to avoid photodegradation of the medium. The experiment took place in duplicate. 
Fourteen RBA-0 (30 mg. L ${ }^{-1}$ of PQT and without sucrose) and 14 RBA-2 (30 mg. L $\mathrm{L}^{-1}$ of PQT and 2 g.L $\mathrm{L}^{-1}$ of sucrose) reactors were operated. Every 24 h, 2 flasks of each reactor (RBA-0 and RBA-2) were removed for the analyses, so that there was no interference in the useful volume of the reactor, totaling 7 days. Control reactors (RC) were also operated as an abiotic factor (without addition of fungus). The RC-0 being a control reactor without addition of sucrose and RC-2 a control reactor with 2 g. $\mathrm{L}^{-1}$ of sucrose.

- Sequential batch reactors with immobilized biomass

Duran flasks with useful of $4.5 \mathrm{~L}$ were used as reactors. The reactor RBS-2 received the synthetic wastewater doped with paraquat and with $2 \mathrm{~g} . \mathrm{L}^{-1}$ of sucrose as a co-substrate, and RBS- 0 , control reactor, received the same amount of synthetic wastewater, but without the addition of co-substrate. The reactors were operated in 5 cycles with 7 days duration each.

For the adherent growth of the biomass the support material used was polyurethane foam, wrapped with polyethylene nets to group the foams and improve immobilization. The material was previously washed with alcohol and distilled water and sterilized in an autoclave at $121^{\circ} \mathrm{C}$ for 20 minutes to remove possible impurities.

Each reactor contained 3 polyethylene nets, with $5 \mathrm{~g}$ of foam in each, which remained in contact with the immobilization nutrient medium (0.75 g.L $\mathrm{L}^{-1} \mathrm{C}_{6} \mathrm{H}_{12} \mathrm{O}_{6}, 0.25$ g.L.- $\mathrm{NaNO}_{3}, 0.25$ g.L.- $\mathrm{MgSO}_{4} .7 \mathrm{H}_{2} \mathrm{O}, 0.01$ g.L.- $\mathrm{CaCl}_{2}$. $\mathrm{H}_{2} \mathrm{O}, 0.5$ g.L.- $\left(\mathrm{NH}_{4}\right)_{2} \mathrm{SO}_{4}, 0.2$ g.L.-1 $\mathrm{KH}_{2} \mathrm{PO}_{4}, 0.05$ g.L.- $\mathrm{MnSO}_{4}, 0.05$ g.L.- $\mathrm{Fe}_{2}\left(\mathrm{SO}_{4}\right)_{3}, 0.08$ g.L $\mathrm{L}^{-1} \mathrm{ZnSO}_{4} .7 \mathrm{H} 2 \mathrm{O}$ and 0.35 g.L $\mathrm{L}^{-1}$ Antibiotic) and Vishniac solution (10.0 gL-1 EDTA, 4.4 gL-1 ZnSO4. $7 \mathrm{H}_{2} \mathrm{O}, 1.0$ g.L $\mathrm{L}^{-1} \quad \mathrm{MnC}_{12} .4 \mathrm{H}_{2} \mathrm{O}$, 0.32 g.L $\mathrm{L}^{-1} \mathrm{CoC}_{12} .6 \mathrm{H}_{2} \mathrm{O}, 0.22$ g.L ${ }^{-1}$ $\left(\mathrm{NH}_{4}\right) 6 \mathrm{MO}_{7} \mathrm{O}_{24} .4 \mathrm{H} 2 \mathrm{O}, 1.47$ g.L. $\mathrm{L}^{-1} \mathrm{CaC}_{12} .2 \mathrm{H}_{2} \mathrm{O}$ and 1.0 g.L $\mathrm{L}^{-1} \mathrm{FeSO} .7 \mathrm{H}_{2} \mathrm{O}$ ) for 24 hours, without artificial aeration, in order to promote the attachment of the fungal spores to the support material. After this period, aeration was started and the growth nutrient medium (1.0 g. L $\mathrm{L}^{-1} \mathrm{C}_{6} \mathrm{H}_{12} \mathrm{O}_{6}, 1.0$ gL $\mathrm{gLNO}_{3}, 0.25$ g.L $\mathrm{L}^{-1}$ gL $\mathrm{NaSO}_{4} .7 \mathrm{H}_{2} \mathrm{O}, 0.01$ g.L $\mathrm{L}^{-1} \mathrm{CaC}_{12} . \mathrm{H}_{2} \mathrm{O}, 2.0$ g.L $\mathrm{L}^{-1}\left(\mathrm{NH}_{4}\right)$ 2SO $\mathrm{SO}_{4}, 0.2$ g.L $\mathrm{L}^{-1} \mathrm{~K}_{2} \mathrm{HPO}_{4}, 0.05$ g.L. $\mathrm{L}^{-1} \mathrm{MnSO}_{4}, 0.05$ g.L $\mathrm{L}^{-1} \mathrm{Fe}_{2}\left(\mathrm{SO}_{4}\right)$ 3, 0.08 g.L $\mathrm{L}^{-1} \mathrm{ZnSO}_{4} .7 \mathrm{H}_{2} \mathrm{O}$ and 0.35 g.L $\mathrm{L}^{-1}$ antibiotic) was changed every 2 days for 10 days, before starting with the pesticide-doped tributary.

The total reaction time for each cycle of the reactors was $144 \mathrm{~h}$, and the reactors were a after 6 days, and the reaction times of $12,24,48,72,96,120$, and $144 \mathrm{~h}$ were studied.

Analyzes performed

Analyses of $\mathrm{pH}$, temperature, Chemical Oxygen Demand (COD), sucrose concentration and Paraquat (PQP) were performed, as well as reaction kinetics.

The $\mathrm{pH}$ and temperature analyses were checked in order to observe the metabolic activity of the fungus, following the APHA (2005) methodology.

The COD analyses were performed with filtered samples, so that there was no influence of the biomass present in the reactor, also following the procedures described by APHA (2005).

The determination of paraquat was performed according to AOAC Method 969.09 (2000), which comprises the reaction between $\mathrm{Na}_{2} \mathrm{~S}_{2} \mathrm{O}_{4}$ - sodium dithionite $1 \%$ (diluted with $\mathrm{NaOH} 0.1 \mathrm{~mol}^{-1}$ ) and samples containing the herbicide, obtaining a blue coloration. Readings were taken in a spectrophotometer at a wavelength of $600 \mathrm{~nm}$.

For the determination of sucrose concentration, a partial hydrolysis (CURTIS et al. (2012) of the samples was necessary, i.e., to break sucrose into reducing sugars (glucose and fructose) to be used as a complement in the EMBRAPA (2013) methodology.

The decay curves of the kinetics of COD and sucrose were performed following the 1st order equation (MARINHO et al. (2017); QUI et al. (2018); BERMÚDEZ et al. (2019); ZHANG et al. (2019); IMAN et al. (2020)) presented in Equation 1.

$\ln [A]_{\mathrm{t}}=-k t+\ln [A]_{0}$ Equation 1.

Being, 
[A]: concentration of reagent $\mathrm{A}$ in mol. $\mathrm{L}^{-1}$;

t: Time (h)

k: Velocity constant $\left(h^{-1}\right)$

The statistical evaluation of each parameter studied was determined by analysis of variance (ANOVA) and comparison by Tukey's Test (95\% confidence level, $p \leq 0.05)$. The programs used were Microsoft Excel, Minitab 17 Statistical Software and OriginLab.

\section{(IV) Adsorption test}

The adsorption test was performed to evaluate the adsorption capacity of PQT by the polyurethane foam used as support medium in the reactors and by the fungal biomass.

The adsorption capacity of PQT on the support medium was evaluated from the initial and final concentration of the pesticide (SILVA, 2015). The same synthetic effluent used in the sequential batch reactors was used. To determine the concentration of PQT during the test, Equation 2 was used.

$$
(\mathrm{mg})=\left(\mathrm{C}_{0}-\mathrm{Ce}\right) \mathrm{x} \mathrm{V}\left(\mathrm{mg} . \mathrm{L}^{-1}\right) \quad \text { Equation } 2
$$

Being,

mg: absorbed PQT mass

$\mathrm{C}_{0}$ : Initial concentration of PQT (mg.L $\left.{ }^{-1}\right)$

Ce: Final concentration of PQT (mg.L $\left.{ }^{-1}\right)$

V: volume (L)

The adsorption capacity of the fungal biomass was performed from the methodology of Barbosa (2016). Initially, an aliquot of fungal biomass was removed from the sequential batch reactors. Subsequently, the PQT present in the sample was removed with methanol addition and followed by centrifugation. At the end, the separation was done with a vacuum membrane. The solid part was characterized from the analysis of volatile suspended solids and the liquid part read in the spectrophotometer.

\section{(V) Contamination test}

At the end of each reaction time in the reactors, aliquots were submitted to the contamination test, which aims to verify the existence of other microorganisms that had not been inoculated, in quantitative terms, which may have arisen during the process. The methodology used was according to APHA (2005).

\section{Results and Discussion}

\subsection{Plaque Toxicity Test}

The toxicity step in plates aimed to evaluate the growth of fungal colonies for 7 days, with different concentrations of pesticide (Figure 1) and define the concentration to be used in sequential batch reactors. 
Figure 1- Petri dishes with different pesticide concentrations.

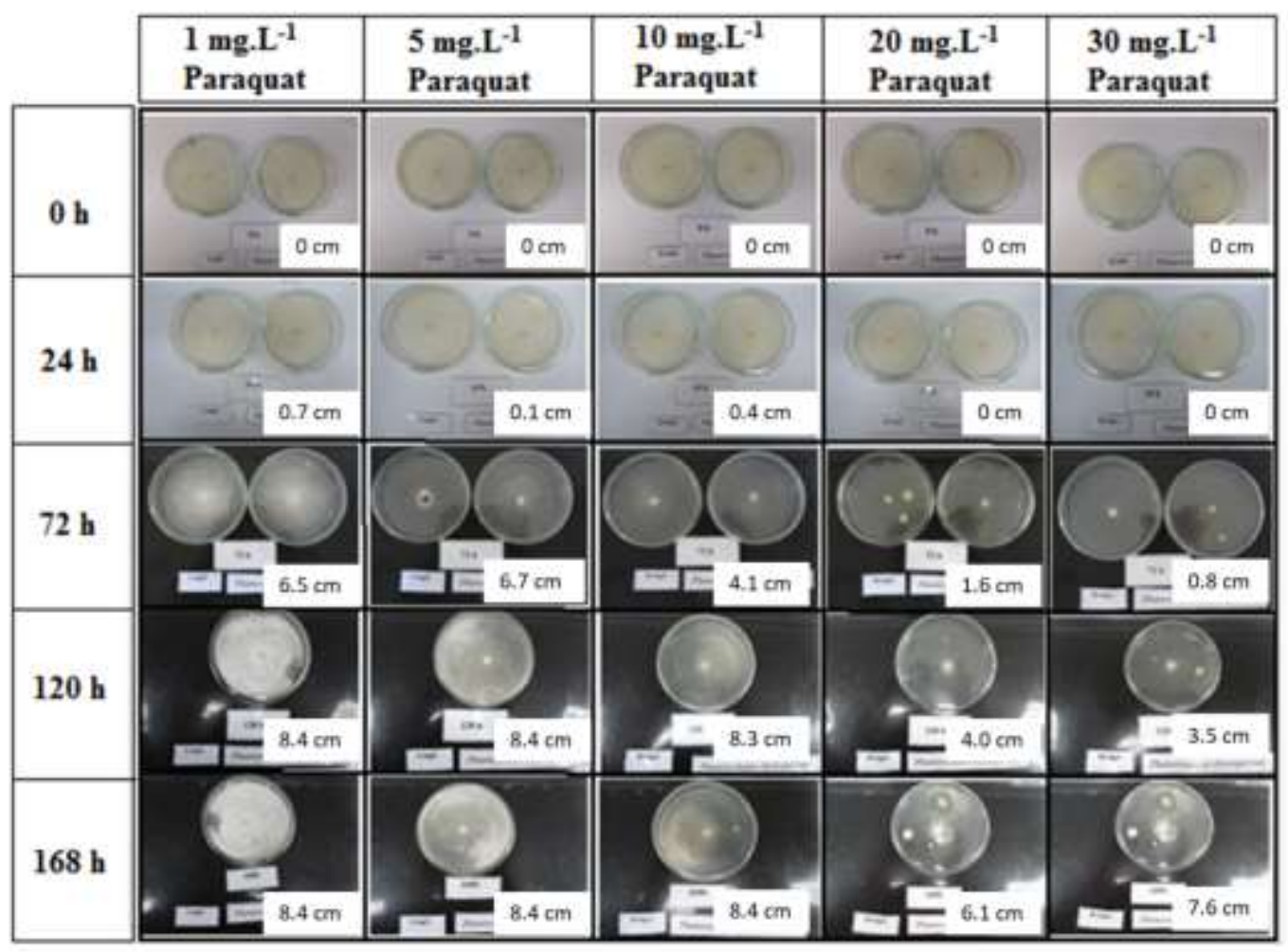

Source: Authors (2021).

The test showed that colonies of the fungus Phanerochaete chrysosporium grew at all pesticide concentrations with maximum diameters of $8.4 \mathrm{~cm}$ (Figure 1). Therefore, we chose to test in batch reactors the highest pesticide concentration supported by the fungus $\left(30 \mathrm{mg}\right.$. $\left.\mathrm{L}^{-1}\right)$.

Therefore, PHC can be a potential microorganism to be used as a bioremediatory in biological reactors. This result corroborates with the fact that filamentous fungi are highly resistant and possess an ability to adapt and grow in unfavorable environmental conditions (BUČKOVÁ et al., 2007). For example, the authors Marinho et al. (2017), also performed the toxicity test with another pesticide, atrazine (concentrations of 0, 5,10, 20 and $30 \mathrm{mg}^{-1}$ ), inoculated with Aspergillus niger AN 400, and in all concentrations, there was fungal growth. In studies with heavy metals, authors Zhao et al. (2016) tested the toxicity of PHC when inoculated with cadmium and lead at $10 \mathrm{mg} . \mathrm{L}^{-1}$ and $30 \mathrm{mg}$. $\mathrm{L}^{-1}$. At all concentrations there was growth of the fungus. Therefore, PHC is also tolerant to these heavy metals.

From this perspective, Wongputtisin et al. (2021) observed that the fungal species Aspergillus tamarii was able to degrade $80 \%$ of PQT in contaminated soil in 15 days, indicating the capacity of these microorganisms to remediate contaminated areas.

\section{$3.2 \mathrm{pH}$ and temperature}

Regarding $\mathrm{pH}$ and temperature, the temperature of the reactors averaged $28 \pm 2{ }^{\circ} \mathrm{C}$. The reactors started with an average $\mathrm{pH}$ of $6.5 \pm 0.5$. Only the RBA-2 reactor presented an average $\mathrm{pH}$ equal to the initial range $(6.28 \pm 0.34)$. The RBS-2 reactor presented the lowest final average $\mathrm{pH}(2.83 \pm 0.11)$ which may be related to the production of by-products formed by the metabolism of the co-substrate (FADIL et al. (2003); LOPES et al. (2011) MARINHO et al. (2017)). The reactors without the addition of sucrose, RBA-0 and RBS-0, showed similar final average $\mathrm{pH} 5.34 \pm 0.44$ and $5.06 \pm 0.21$, respectively. 
According to Han et al. (2014) and Reyna et al. (2017), the best pesticide removals occur at acidic pH, as it enhances the enzymatic activity of the fungi and favors the degradation process. The $\mathrm{pH}$ being close to 5 , the best for the growth of most fungal species.

\subsection{Influence of sucrose on paraquat degradation}

The results of the removal efficiencies of PQT, consumption of sucrose and degradation kinetics constants from the stirred-batch reactors with dispersed biomass and in sequencing with immobilized biomass, inoculated with Phanerochaete chrysosporium are presented in Table 1.

Table 1. Efficiency of paraquat removal and sucrose consumption and respective kinetic constants

\begin{tabular}{|c|c|c|c|c|}
\hline & PARAQUAT & & & SACAROSE \\
\hline & Remoção (\%) e DV* & $k\left(h^{-1}\right)$ e $D^{*}$ & $\begin{array}{l}\text { Consumo (\%) } \\
\text { DV* }\end{array}$ & e $\quad k\left(h^{-1}\right)$ e $D^{*}$ \\
\hline RBA-0 & $3,1 \pm 0,02^{a}$ & $0,09 \pm 0,001^{a}$ & & $\mathrm{NA}^{* *}$ \\
\hline RBA-2 & $21,1 \pm 0,52^{b}$ & $0,015 \pm 0,002^{b}$ & $56,5 \pm 0,05^{a}$ & $0,016 \pm 0,001^{a}$ \\
\hline RBS-0 & $41,1 \pm 0,89^{c}$ & $0,002 \pm 0,001^{c}$ & & $N A^{* *}$ \\
\hline RBS-2 & $34,3 \pm 2,31^{d}$ & $0,018 \pm 0,002^{b}$ & $92,4 \pm 0,864^{b}$ & $0,147 \pm 0,001^{b}$ \\
\hline
\end{tabular}

RBA- $0=$ stirred batch reactor without addition of sucrose; RBA-2 = stirred batch reactor with 2 g.L $\mathrm{L}^{-1}$ sucrose; RBS- $0=$ sequential batch reactor without addition of sucrose; RBS-2 = sequential batch reactor with 2 g.L. $\mathrm{L}^{-1}$ sucrose.

$* \mathrm{SD}=$ Standard Deviation; **NA= Not Rated. The values expressed correspond to the average removal and consumption.

Means that do not share a letter in the same column are significantly different, by the Tukey test $(95 \%$ confidence level, $p \leq 0.05)$. The assumptions for the analysis of the ANOVA were evaluated. Source: Authors (2021).

In all reactors there was removal of PQT. Being that the sequential batch reactor without addition of sucrose, RBS-0, obtained efficiency of $41.1 \pm 0.89 \%$ and with sucrose, RBS-2, obtained $34.3 \pm 2.31 \%$. Therefore, the addition of the cossubstrate did not influence positively for the removal of PQT in the sequencing reactors. However, in the stirred batch reactors, the addition of sucrose improved the efficiency of PQT removal. RBA-2 obtained $21.1 \pm 0.52 \%$ and RBA-0 only 3.1 \pm 0.02 .

Analyzing the sucrose consumption, RBS-2 was the one that consumed more sucrose $(92.4 \pm 0.66 \%)$ when compared to the other reactor that had sucrose added, RBA-2 $(56.5 \pm 0.02)$.

It is noteworthy that greater removal of PQT was observed in reactors with sucrose in sequential batch (RBS-2) when compared to reactors with stirred batch also containing an external source of carbon (RBA -2), which may indicate that for the consumption of PQT, the form of fixation of the microorganism on the support medium may influence the achievement of better removal percentages, as already reported by Bouabidi, El-Naas and Zhang (2019).

Statistically, the means of PQT removal of the 4 reactors are significantly different from each other. However, although fungal metabolism and growth are positively influenced by the presence of glucose (YAO et al., 2013), the noninfluence of sucrose, in this research, is due to the fact that the microorganisms used the pesticide as a carbon source. The addition of a cossubstrate also influenced negatively in the study of the authors Silva et al. (2013), when testing the ability Cunninghamella elegans to degrade phenanthrene in aqueous medium with the addition of glucose, the highest concentration 
added ( 1 g.L $\left.\mathrm{L}^{-1}\right)$ inhibited the cell growth of the fungus. In contrast, the authors Silva et al. (2018) had better paraquat removal results (70\%) when added 1 g.L. - $^{-1}$ of glucose and 1 g.L. $\mathrm{L}^{-1}$ of cassava peel in batch reactors inoculated with Aspergillus niger AN 400 , with reaction time of $168 \mathrm{~h}$ with initial concentration of $30 \mathrm{mg} \cdot \mathrm{L}^{-1}$ of PQT. The removal efficiency was higher than in this work, but two carbon sources were used, which may have been more easily assimilated by the fungus than sucrose. As well, the cassava husk may have been a source of extra fiber and micronutrients for the environment.

When using ethanol as a cosubstrate $\left(4 \mathrm{~g} . \mathrm{L}^{-1}\right)$ for degradation of the pesticide Methyl Paration $\left(1 \mathrm{~g} . \mathrm{L}^{-1}\right)$ in stirred batch reactors with dispersed biomass of Aspergillus niger AN 400, the authors Freitas et al. (2017) obtained 73\% removal efficiency.

From the kinetic study, it was possible to evaluate the influence of the cosubstrate on the degradation of PQT. The degradation curve profiles of the reactors (Figure 3) followed the first order reaction and the constant $k$ was calculated in OriginPro 6 software.

Figure 2. Paraquat degradation curve profiles of the RBA-0, RBA-2, RBS-0 and RBS-2 reactors.

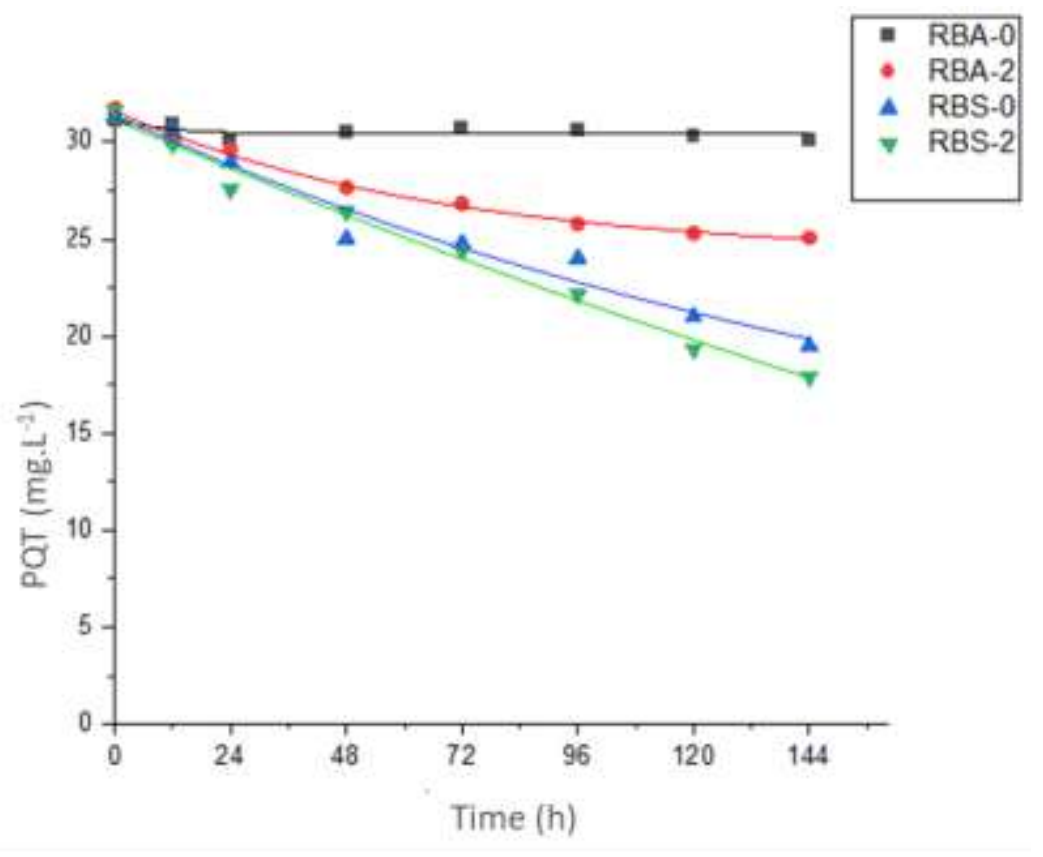

RBA-0 = stirred batch reactor without addition of sucrose; RBA-2 = stirred batch reactor with 2 g.L - $^{-1}$ sucrose; RBS- $0=$ sequential batch reactor without addition of sucrose; RBS-2 = sequential batch reactor with 2 g. $\mathrm{L}^{-1}$ sucrose. Source: Authors (2021).

In this present study, it was observed that the decay curve of the reactor RBA-0 did not fit as degradation. It was also found that the reactors with sucrose addition, RBA-2 and RBS-2, obtained better average kinetic rates, $0.015 \mathrm{~h}^{-1}$ and $0.018 \mathrm{~h}^{-1}$, respectively. Therefore, the addition of sucrose influenced the rate of degradation of the pollutant. When statically evaluated, the two reactors showed no significant differences between them with respect to the kinetic constants. The authors Silva et al. (2018), also found higher removal speed of PQT $\left(\mathrm{k}=0.2051 \mathrm{~h}^{-1}\right)$, but were added $3 \mathrm{gL}^{-1}$ of glucose, a higher concentration than the sucrose concentration used, in this work.

The difference in sucrose consumption may be due to the type of biomass used and consequently may also have influenced the removal of PQT. The use of dispersed biomass with stirring, the $\mathrm{pH}$ and temperature range in the stirred batch reactors resulted in a pellet-like fungal growth (Figure 3). 
Figure 3. Pellet formation in stirred batch reactors (RBA-0 and RBA-2).

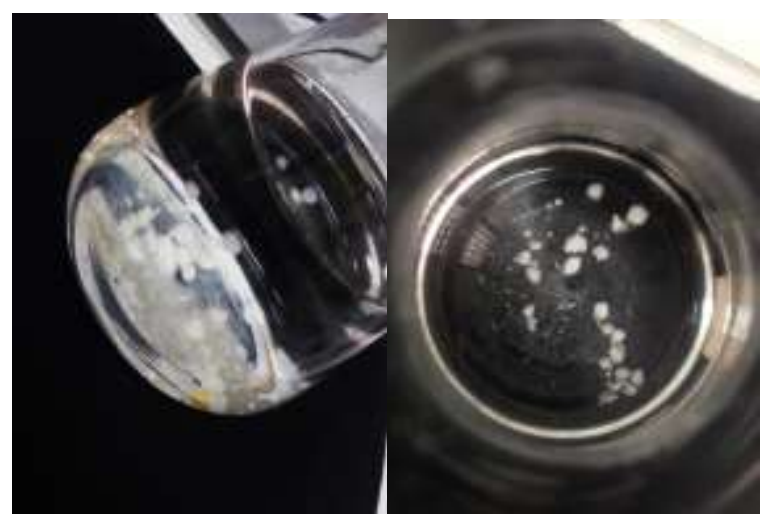

Source: Authors (2021).

These pellets are small spheres of hyphae (Papagianni, 2004) and this format makes it difficult for nutrients to reach the interior of the pellets when they are in larger sizes, so the pellets must have small sizes to avoid the emergence of nutritional deficiency (GIBBS et al., 2000; KRULL et al., 2013). Therefore, the formation of these pellets in the RBA-0 and RBA-2 reactors cannot have influenced the low removal of the PQT since the sucrose consumption was only $56.5 \pm 0.05 \%$ and a consumption rate of $0.0166 \mathrm{~h}^{-1}$.

The highest PQT removal means occurred in sequential batch reactors with immobilized biomass $(\mathrm{RBS}-0=41.1 \pm$ $0.89 \%$; RBS-2 $=34.3 \pm 2.31 \%$ ). According to the authors De Filippi and Lewandowski (1998) and Jou and Huang (2003), the use of immobilized biomass has four main advantages, namely: simplicity of operation, ability to withstand shocks from organic loads, low solids production, and beyond Furthermore, little energy is needed. Furthermore, the use of immobilized biomass reduces the adaptation time (Sharma \& Gupta, 2012) and offers great efficiency and stability to the process, especially when a high degradation rate is needed (Alves, 1999).

Therefore, these statements corroborate the results of this study, as the sequential batch reactors with immobilized biomass favored the removal of the pollutant and were the ones with the best removals of PQT $(\mathrm{RBS}-0=41.1 \pm 0.89 \%)$ and best mean sucrose consumption and kinetic constant, $92.4 \pm 0.864 \%$ and $0.147 \mathrm{~h}^{-1}$ for the RBS-2 reactor. Figure 4 a shows the sequential reactor with the support material and Figure $4 \mathrm{~b}$ shows the reactor 15 days after fungus inoculation and the biomass already formed.

Figure 4a- Sequential Reactor with medium and support material; 4b - Sequential Reactor 15 days after fungus inoculation and biomass already formed.

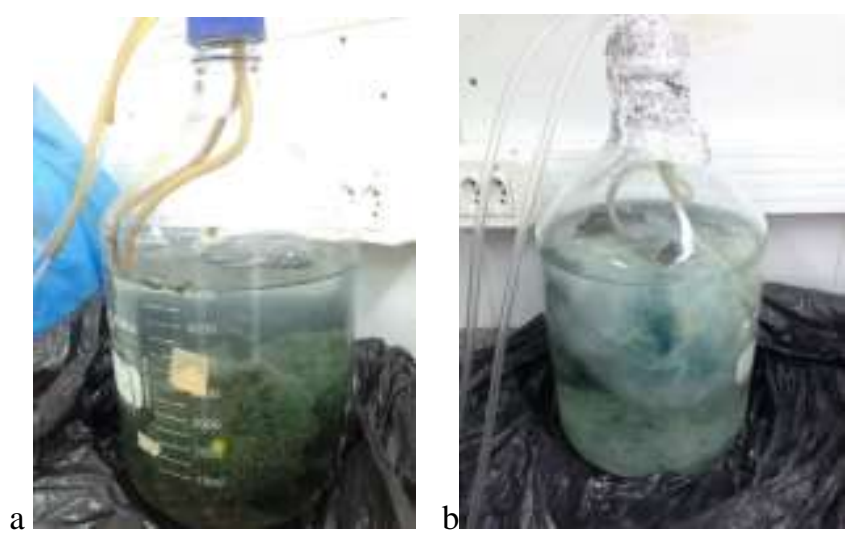

Source: Authors (2021). 


\subsection{Influence of sucrose on organic matter degradation in terms of COD}

The influence of sucrose on COD degradation was evaluated only in reactors RBS-0 and RBS-2, with mean initial concentrations of $959.13 \pm 53.1 \mathrm{mg}$. L ${ }^{-1}$ and $2424.58 \pm 236.7 \mathrm{mg}$. L ${ }^{-1}$, respectively. Even without sucrose addition, the RBS-0 reactor still presents organic matter because of the synthetic effluent. The highest removals in RBS-2 occurred in the fourth and fifth cycle, presenting $80.8 \%$ and $80.4 \%$, respectively. The average COD removal efficiency of all cycles of RBS-2 was $79.9 \% \pm 0.95$, as shown in Table 5 .

Table 2- COD removal efficiency and degradation rate of RBA-0, RBA-2, RBS-0 and RBS-2 reactors.

\begin{tabular}{|c|c|c|c|c|}
\hline & RBS-2 & & RBS-0 & \\
\hline \multirow[t]{2}{*}{ Cycles } & Removal efficiency & & Removal efficiency & \\
\hline & of COD (\%) & $\mathbf{k}\left(\mathbf{h}^{-1}\right)$ & of $\operatorname{COD}(\%)$ & $\mathbf{k}\left(\mathbf{h}^{-1}\right)$ \\
\hline 1 & 78,07 & 0,015 & 70,10 & 0,008 \\
\hline 2 & 80,03 & 0,015 & 77,16 & 0,007 \\
\hline 3 & 80,23 & 0,012 & 70,52 & 0,005 \\
\hline 4 & 80,80 & 0,016 & 79,01 & 0,003 \\
\hline 5 & 80,40 & 0,012 & 74,67 & 0,008 \\
\hline & $79,9 \% \pm 0,95^{\mathrm{a}}$ & & $75,4 \% \pm 2,8^{\mathrm{a}}$ & \\
\hline MEAN & & $0,014 \pm 0,001^{\mathrm{a}}$ & & $0,006 \pm 0,002^{\mathrm{b}}$ \\
\hline
\end{tabular}

Source: Authors (2021).

Means that do not share a letter on the same line are significantly different, according to the Tukey test (95\% confidence level, $\mathrm{p} \leq 0.05$ ). The assumptions for the analysis of the ANOVA were evaluated. Source: Authors (2021).

In RBS-0, the highest average removals of COD occurred in the fourth and second cycles, presenting $79.6 \%$ and $77.2 \%$, respectively. The average COD removal efficiency in all cycles of RBS- 0 was $75.4 \% \pm 2.8$. Statistically, the means of COD removal are not significantly different. Therefore, the addition of sucrose did not influence positively on the removal of organic matter, however, as mentioned earlier, the addition of sucrose favored the removal speed of the PQT. Figure 5 shows the decay profiles of COD. 
Figure 5a- COD decay profiles in the RBS-2 reactor; 5b- COD decay profiles in the RBS-0 reactor.

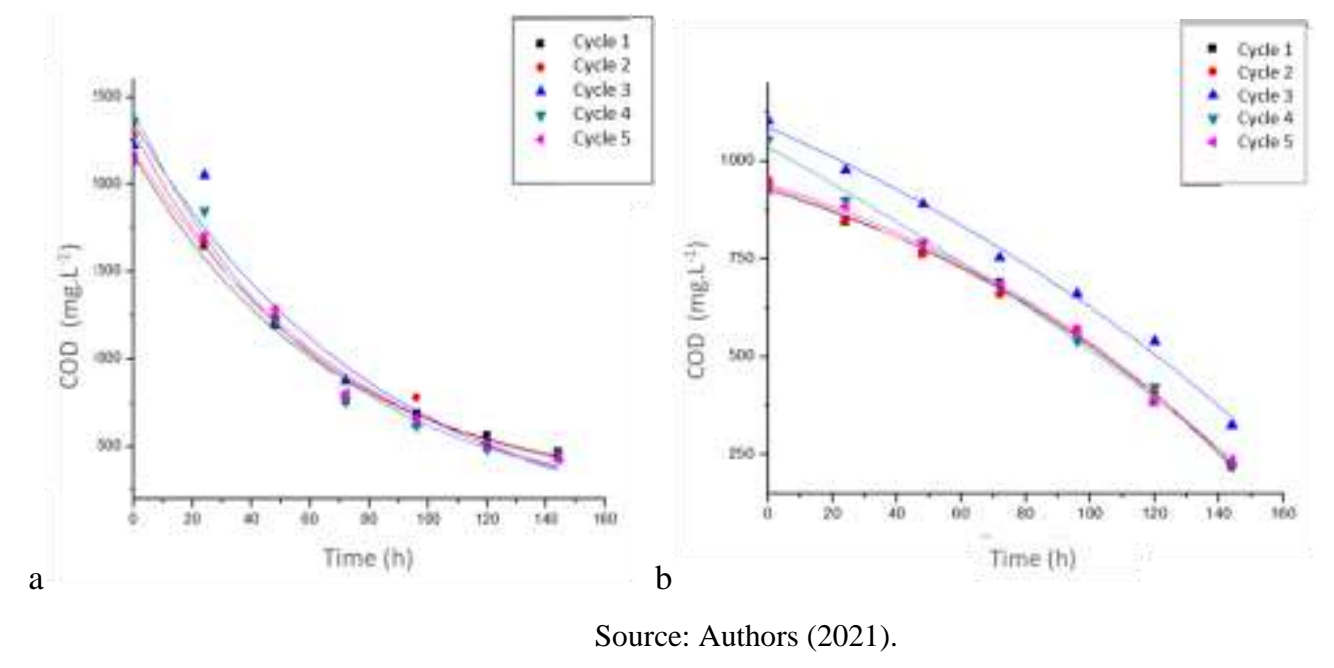

The COD removal reaction followed first order kinetics. The speed in which the COD was removed, during the final reaction time of $144 \mathrm{~h}$, in RBS-2 presented an average of the kinetic constant of $0.014 \pm 0.001 \mathrm{~h}^{-1}$, being the fourth cycle the fastest in the removal $\left(0.016 \mathrm{~h}^{-1}\right)$. As for RBS-0, the average kinetic constant was $0.006 \pm 0.002 \mathrm{~h}^{-1}$, with the first and fifth cycles being the fastest in removal $\left(0.008 \mathrm{~h}^{-1}\right)$. However, the fifth cycle besides being faster, presented a higher efficiency in the removal of COD compared to the first cycle. Therefore, the addition of sucrose negatively influenced the rate at which COD was removed, since the reactor without sucrose (RBS-0) had a rate 2 times faster than the reactor with sucrose (RBS-2). According to Singh (2006), the optimal concentration of the bio-substrate to be used depends on the microbial species, the type of pollutant and the type of reactor.

When adding $3 \mathrm{mgL}^{-1}$ of glucose in the sequential batch reactor inoculated with Aspergillus niger AN 400, the authors Marinho et al. (2017) obtained better COD removal $(50 \pm 3 \%)$ when compared to the reactor without glucose $(25 \pm 4 \%)$, these values are lower than those found in this study with the addition of sucrose, which may be associated with co-substrate used.

\subsection{Adsorption test}

Initially, the adsorption test was performed on the support material used in the sequential batch reactors to verify the amount of adsorbed paraquat. The saturation point reached by the pollutant was 2 minutes with a maximum capacity of 0.0001 $\mathrm{g}$ of PQT per gram of support material. The total mass balance of pesticide removed by reactors RBS- 0 and RBS- 2 was averaged and an average removal of $0.00259 \mathrm{~g}$ of PQT was verified. Therefore, the reactor with $15 \mathrm{~g}$ of support material has $0.000173 \mathrm{~g}$ of PQT for each gram of support material. Since the maximum adsorption capacity of the foam was $0.0001 \mathrm{~g}$, the value found in the degradation of MDP in the reactors was higher than the maximum capacity, meaning that adsorption was not the main removal mechanism. Therefore, the fungus Phanerochaete chrysosporium collaborated with the degradation.

The adsorption test was also performed on the fungal biomass. $0.00090 \mathrm{~g}$ of COD was absorbed for $15.2 \mathrm{~g}$ of total biomass. Therefore, the removal via adsorption in the biomass was only 1.7\%. According to Pinto et al. (2012), that there are few studies on fungal degradation that perform the adsorption test and that each fungal species has different adsorption processes. 


\subsection{Contamination assessment in reactors}

The contamination evaluation was performed at the end of each cycle in each reactor. It consists in verifying the predominance of the fungus at the end of each treatment. In all reactors the presence of fungus was higher than that of bacteria (Table 3). Therefore, the degradation of the PQT and COD was predominantly done by fungal action.

Table 3 - Presence of fungus and bacteria of each cycle in each reactor.

\begin{tabular}{|l|c|c|c|c|}
\cline { 2 - 5 } \multicolumn{1}{c|}{} & RBA-0 & RBA-2 & RBS-0 & RBS-2 \\
\hline Bacteria (UFC. $\mathrm{mg}^{-1}$ ) & 1600 & 1752 & 1500 & 1450 \\
\hline Fungus (UFC. $\mathrm{mg}^{-1}$ ) & 1810 & 2313 & 2100 & 3550 \\
\hline
\end{tabular}

Source: Authors (2021).

\section{Conclusion}

From the toxicity test it was verified that the microorganism Phanerochaete chrysosporium under different concentrations of paraquat, was resistant to all concentrations tested.

In relation to the addition of sucrose in the reactors, this did not influence positively in the efficiency of pesticide and COD removal, however, the addition of the co-substrate influenced the speed of degradation of the PQT and COD, since the reactors with the addition of sucrose were the ones that presented the highest kinetic constants.

It was possible to observe that the reactors with immobilized biomass showed better removal of PQT when compared to the reactors with dispersed biomass.

In both types of reactors the presence of fungi was higher than that of bacteria, therefore the removal of paraquat and COD was predominantly done by fungal action.

As a suggestion for future work, evaluate the performance of other fungal species in the biological treatment of pesticides, as well as other possibilities for using a co-substrate that has a lower cost.

\section{Acknowledgments}

We would like to thank the CNPQ and IFCE - Brasil for Financial Support.

\section{References}

Abhilash, P. C. \& Singh, N. (2009) Pesticide use and application: An Indian scenario. Journal of Hazardous Materials, 165, 1-12.

ANVISA (2005) Controlando agrotóxicos nos alimentos: O trabalho desenvolvido pela ANVISA, com as vigilâncias sanitárias dos estados do AC, ES, GO, $M G, M S, P A, P E, P R, R J, R S, S C, S P$, TO, a FIOCRUZ/INCQS e os laboratórios IAL/SP, ION/FUNED, LACEN/PR E ITEP/PE. Relatório de atividades 20012004. Brasília.

APHA (2005) Standard methods for the examination of water and wastewater. $21^{\text {st }}$ edition. Washington, D.C. American Health Association.

Barbosa, B. C. A. (2016) Micodegradação de metil paration e atrazina em matriz aquosa sintética utilizando aspergillus niger an 400. Tese (Doutorado) Curso de Pós-graduação em Engenharia civil - Saneamento ambiental, Universidade Federal do Ceará, Fortaleza, 125pp.

Bernoth, L., Firth, I., Mcallister, P. \& Rhodes, S. (2000) Biotechnologies for remediation and pollution control in the mining industry. Miner. Metall. Proc, 17, $105-111$.

Bermudez et al. (2019) Estudo da degradação do paraquat em regime de batelada agitada inoculados com phanerochaete chrysosporium com adição de glicose ou sacarose. Revista AIDIS, 12 (13), 432-452.

Bouabidi, Z., B., El-Naas, M., H. \& Zhang, Z. (2019) Immobilization of microbial cells for the biotreatment of wastewater: A review. Environ Chem Lett , 17, 241-257. 
Bucková, M., Godocikova, J. \& Polek, B. (2007) Responses in the mycelial growth of Aspergillus niger isolates to arsenic contaminated environments and their resistance to exogenic metal stress. J Basic Microbiol. 47(4), 295-300.

Curtis, M.J., Donald, D.A \& Ridd, M. (2012) Determination of Sucrose and Glucose in Sugarcane Using a Glucose Biosensor. Proc Aust Soc Sugar Cane Technol, 34, 1-11.

Das, S. \& Dash, H. R. (2014) Microbial Bioremediation: A Potential Tool for Restoration of Contaminated Areas. Microbial Biodegradation and Bioremediation, 1-21.

De Filippi, L.J. \& Lewandowski, G.A., 1998. Biological Treat-ment of Hazardous Wastes. John Wiley and Sons. ISBN no.0-471-0486-5.

Dong, X.S., Xu, X.Y, Sun, Y.Q., Wei-Liu, J. Zh. \& Liu, Z. (2013)Toll-like receptor 4 is involved in myocardial damage following paraquat poisoning in mice. Toxicology, 312, 115-122.

EMBRAPA, Empresa Brasileira de Pesquisa Agropecuária (2013) Determinação de açúcares redutores pelo ácido 3, 5-dinitrosalicílico: histórico do desenvolvimento do método e estabelecimento de um protocolo para o laboratório de bioprocessos. Fortaleza: Embrapa Agroindústria Tropical.

Fadil, K., Chahlaoui, A., Ouahbi, A., Zaid, A. \& Borja, R. (2003) Aerobic biodegradation and detoxification of wastewaters from the olive oil industry. International Biodeterioration \& Biodegradation, 51, 37-41.

Freitas, L., Barbosa, B., Rodrigues, K \& Marinho, G. (2017) Emprego de Aspergillus niger AN 400 em reatores de bancada para remover pesticida de matriz aquosa. Rev. Eng Sanit Ambient, 22 (6), 1175-1185.

Fukushima,T., Tanaka, K., Lim, H. \& Moriyam, M. (2002) Mechanism of cytotoxicity of paraquat. Environ. Health Prev. Med., 7 , 89-94.

Galic, N., Sullivan, L. L., Grimm, V. \& Forbes. V. E. (2018) When things don't add up: quantifying impacts of multiple stressors from individual metabolism to ecosystem processing. Ecology Letters, 21(4), 568-577.

Gibbs, P. A., Seviour, R. J. \& Schmid, F. (2000) Growth of filamentous fungi in submerged culture: Problems and possible solutions. Critical Reviews in Biotechnology, 20 (1),17-48.

Han, J., Fang, P., Xu, X., Li-Zheng, X., Shen, H. \& Ren, Y. (2015) Study of the pesticides distribution in peel, pulp and paper bag and the safety of pear bagging. Food Control, 54, 338-345.

Hyland, C. \& Laribi, O. (2017) Review of take-home pesticide exposure pathway in children living in agricultural áreas. Environmental Research, 156, 559570 .

Iman, A.S., Zouari, N. \& Al-Ghouti, M.A. (2020) Removal of pesticides from water and wastewater: Chemical, physical and biological treatment approaches. Environmental Technology \& innovation, 9, e101026.

Jou, C. G. \& Huang, G. (2003) A pilot study for oil refinery wastewater treatment using a fixed film bioreactor. Advances in Environmental Research, 7, 463469.

Keawkumay et al. (2019) Paraquat adsorption on NaY zeolite at various Si/Al ratios: a combined experimental and computational study. Mater. Chem. Phys., $238, \mathrm{e} 121824$

Krull et al. (2013) Characterization and control of fungal morphology for improved production performance in biotechnology. Journal of Biotechnology, $163,112-123$

Lemarchand et al. (2017) Cancer incidence in the AGRICAN cohort study (2005-2011). Cancer Epidemiology, 49, $175-185$.

Lerro et al. (2019) Cancer incidence in the Agricultural Health Study after 20 years of follow-up. Cancer Causes Control, 30 (4), $311-322,2019$.

Lopes, M. S. S., Oliveira, P. C. C., Andrade, M. V. F., Araújo, R. S., Marinho, G.\& Rodrigues, K. (2011) Remoção de macronutrientes de efluente da indústria de castanha de caju por uso de reator aeróbio em batelada com inóculo fúngico. Rev. Eng Sanit Ambient, 16 (1), $17-26$.

Lopes, C.V.A.\& Albuquerque, G.S.C. (2018) Agrotóxicos e seus impactos na saúde humana e ambiental: uma revisão sistemática. Revista Saúde debate, 45 (117), 518-534

Marinho et al. (2017) Potential of the filamentous fungus Aspergillus niger AN 400 to degrade Atrazine in wastewaters. Bioctalysis and agricultural Biotechnology, 9, 162-167.

Ottoni. (2012) Descoloração de corantes têxteis por fungos elevada. Tese (Doutorado em Engenharia Química e biológica). Universidade do Minho, Braga, $51 \mathrm{p}$.

Papagianni, M. (2004) Fungal morphology and metabolito production in submerged mycelial processes. Biotechnology Advances. 22, 189-259.

Pandiselvam et al. (2020) Ozone as a novel emerging technology for the dissipation of pesticide residues in foods-a review. Trends Food Sci. Technol., 97, 3854.

Pereira, P. M. Avaliação do potencial de fungos na degradação do herbicida atrazina. 2011. 92f. Dissertação (Mestrado) - Curso de Pós-Graduação em Vigilância Sanitária, Instituto Nacional de Controle de Qualidade em Saúde, Rio de Janeiro -RJ.

Pereira et al (2018). Methodology of cientific research. [e-Book]. Santa Maria City. UAB / NTE / UFSM Editors. Available at: https://repositorio.ufsm.br/bitstream/handle/1/15824/Lic_Computacao_Metodologia-Pesquisa-Cientifica.pdf?sequence=1 . 
Qi, H., Huang, Q. \& Hung, Y. (2018) Effectiveness of electrolyzed oxidizing water treatment in removing pesticide residues and its effect on produce quality. Food chemistry, 239, 561-568.

Reyna, L., Gerardo, J. L., Navarro, G. \& Sanchez, J.E. (2017) Producción de enzimas ligninolíticas durante la degradación del herbicida paraquat por hongos de la pudrición blanca. Revista Argentina de Microbiología, 49 (20), 189-196.

Rowland, G. A., Bausch, A. R.\& Grannas, A. M. (2011) Photochemical processing of aldrin and dieldrin in frozen aqueous solutions under arctic field conditions. Environmental Pollution, 159, 1076-1084.

Sánchez et al. (2013) Removal of triazine herbicides from aqueous systems by a biofilm reactor continuously or intermittently operated. Journal of Environmental Management, [s.1], 128.

Serra, A., Domingos, F. \& Prata, M. M. (2013) Intoxicação por Paraquat. Acta Médica Portuguesa, 16, 25-32.

Sharma, N., Gupta, V.C. (2012) Comparative biodegradation analysis of phenol from paper \& pulp industrial effluent by free and immobilized cells of Aspergillus niger. In: Anais...International Conference on Environmental Science and Technology IPCBEE, v. 30, Meerut.

Silva, L.C.N. Degradação biológica de paraquat em reatores em bateladas por biomassa fúngica. 89 f. Dissertação (Mestrado em Tecnologia e Gestão Ambiental). Programa de Pós-Graduação em Tecnologia e Gestão Ambiental do Instituto Federal do Ceará - PGTGA/IFCE, 2015.

Silva et al. (2018) Biodegradação de paraquat e produção de celulase em reatores inoculados com fungos e resíduo lignocelulósico. Rev. Eng Sanit Ambient 66 (211), 50-61.

Silva, K. M. L. Tratamento de efluente têxtil in natura por Aspergillus níger AN 400 inoculado em reator em bateladas sequenciais. Dissertação (Mestrado em Tecnologia e Gestão Ambiental). Programa de Pós-Graduação em Tecnologia e Gestão Ambiental do Instituto Federal do Ceará - PGTGA/IFCE, 2013.

Sorolla, M. G., Dalida, M. L., Khemthong, P., Grisdanurak, N. \& Srinivasan, P. Paraquat: a unique contributor to agriculture and sustainable development. Prasanna Srinivasan. India, 2004.

Suo, F., Liu, X., Li, C., Yuan, M., Zhang, B., Wang, J., Ma, Y., Lai, Z. \& Jia, M. (2019) Mesoporous activated carbon from starch for superior rapid pesticides removal. Int. J. Biol. Macromol., 121, 806-813.

Vasconcelos, Y. (2018) Agrotóxicos na berlinda, Revista Pesquisa Fapesp, São Paulo, 271, 18-27.

Yao et al. (2013) Determination of paraquat in water samples using a sensitive fluorescent probe titration method. Journal of Environmental Sciences, 25 (6), $1245-1251$.

Zhang, D.H., Zhao, L., Wang, D.X. \& Meng, D. (2019) A review on fenton process for organic wastewater treatment based on optimization perspective. Sci. Total Environ., 670, 110-121.

Wesseling et al. (2001) Paraquat in developing countries. Int. J. Occup. Environ. J. Health, 7, 275-286.

Wongcharoen, S \& Panomsuwan, G. (2018) Easy synthesis of $\mathrm{TiO}_{2}$ hollow fibers using kapok as a biotemplate for photocatalytic degradation of the herbicide paraquat. Mater. Lett., 228, 482-485.

Wongputtisin, P., Supo, N., Suwannarach, Y., Honda, T., Nakazawa, J., Kumla, S. \& Lumyong, C. (2021) Filamentous fungi with high paraquat-degrading activity isolated from contaminated agricultural soils in northern Thailand. International Journal of Applied Microbiology, 72 (4), $467-475$.

Wu, W.P., Lai, M.N., Lin, C.H., Li, Y.F., Lin, C.Y. \& Wu, M.J. (2014) Addition of immunosuppressive treatment to hemoperfusion is associated with improved survival after paraquat poisoning: a nationwide study. PLOS ONE, 9 , e87568. 